\title{
A STUDY ON ACTIVITIES RELATED TO HABITATION (INDWELLING) AND THEIR MEANINGS
}

\author{
Ewa Stachura, Assoc. prof., PhD \\ Institute for Built Environment Studies \\ University of Economics in Katowice \\ e-mail:ewa.stachura@ue.katowice.pl
}

Katarzyna Binkowska, M.A.

\begin{abstract}
The process of transformation in Poland contributed to the dynamic development of the housing market and caused a growth of aspirations among Poles related to the housing environment. The diversity of lifestyles has brought about new, different expectations of the residential environment. Meanwhile, most surveys examining housing preferences and focused on the location of housing, services and infrastructure in housing estates, and urban and architectural standards show similar expectations of residents in regards to their housing environment. The phenomenon of the homogenization of expectations regarding the residential environment appears regardless of the household lifecycle, place of residence, or level of wealth (STACHURA 2013).

Research methods testing users' preferences allow an expected set of characteristics of the housing environment to be specified. If the respondents' aspirations regarding the housing environment are similar regardless of the segment they belong to, it may be assumed that possible differences may be revealed by a more detailed study.

People perform many activities in their homes. These activities are related to everyday living, family and social life, work or hobbies. Each of them may be in assigned to one or more rooms in a dwelling. Activities may have different meanings and hold a different degree of importance to the residents. When purchasing a new dwelling, buyers prefer homes where the activities most important to them can be carried out in the most satisfactory way. The study attempts to establish the relationships between activities and sub-settings (dwelling or residential environment features) as well as between activities and their meanings.

This paper presents an extended method of examining residential preferences: respondents declare, in a survey questionnaire, what activities are carried out in the dwelling, and how they attach meanings to these activities. The pilot study showed that some of the activities are strongly associated with one specific room, while others may be connected to any room. Rooms in Polish homes have many functions. Some of the functions are strictly connected with the type of room (bedroom, bathroom), but there is also a set of everyday activities that can be assigned to different rooms, selected by the resident. The present research revealed that activities can take on different meanings, which determines their level of importance to the dwelling user.
\end{abstract}

Key words: Housing Preferences, Residential Environment, Activities in the Dwelling, Meanings of Activities.

JEL Classification: R30, D03, D70.

Citation: Stachura E., Binkowska K., 2014, A study on activities related to habitation (indwelling) and their meanings, Real Estate Management and Valuation, vol. 22, no. 3, s. 5-13.

DOI: $10.2478 /$ remav-2014-0022 


\section{Introduction}

Poland is currently experiencing a dynamic development of the housing market and rapid advances in building technology. Nowadays, various sources of media provide unrestricted access to information about national and foreign achievements in architecture and urban design. All kinds of building materials and elements of interior design are also presented in architectural journals as well as on the Internet. The above-mentioned information inspires residents and encourages them to model their homes according to their needs and aesthetic preferences. Nowadays, the floor plans of dwellings can precisely follow residents' preferences, even with the rapidly proceeding processes of lifestyle diversification.

A nationwide survey of housing preferences in Poland relates to the issues of housing estate location, access to services and dwelling standard. The research results show a high degree of homogenization of residents' expectations as to the housing environment, regardless of the phase in their lifecycles, place of residence, level of wealth or lifestyle. Such results serve as motivation for conducting further studies regarding housing preferences and extending their scope, which would allow for differences in expectations as to the housing environment to be revealed.

The housing market is much more than merely a part of the real estate market; it is a place that meets the basic needs of each person (NYKIEL 2006), who spends very significant amounts of time at home, performing various activities within its confines.

Good design and existing conveniences make it possible to gain satisfaction residing in a dwelling, which is a central setting in people's everyday life. This may be deduced from the diverse meanings of the word. "Dwelling" can have a functional meaning - for example, having a roof over one's head. Dwelling can also have a social meaning - for example, being together with family or friends (MEESTERS 2009). The dwelling itself can be an indicator of one's position in society, or people may regard it as an economic investment. Most of these meanings are related (either directly or indirectly) to the wide range of activities which occur within the home. In this light, dwellings can be legitimately studied as the centres of day-to-day activities. It can be said that people prefer such dwellings (homes) which allow them to freely go about their activities and fulfill all their needs. The identification and analysis of activities carried out within dwellings and their meaning can help to design a better housing environment.

\section{Rooms in the dwelling and related activities (research results)}

\subsection{Impact of lifestyles and the system of values in examining housing preferences.}

The housing market is treated as a separate segment of the real estate market. The reason is that dwellings play such an important role in lives of households and individuals (STRĄCZKOWSKI 2009). A dwelling is one of the basic goods of humans, providing a basis for social cooperation and engagement in family life, as well as shaping one's identity (BUCKENBERGER 2012). Every single person is a potential buyer in the housing market. The variety of real estate offered, their physical properties and the assumption that each person is a consumer in this market makes it a subject of interdisciplinary research.

The aim of studies on housing preferences is their identification and prognosis. Their findings increase knowledge on housing needs and consumers' behaviors on the housing market (HEIJS et al. 2011). Human behavior regarding habitation can be understood as the resultant of lifestyle and routine activities deeply rooted in culture (e.g., going to work, cleaning the apartment). These activities form a repetitive 24-hour scheme (VAN DIEPEN, MUSTERD 2009). It can therefore be concluded that potential buyers' behavior in the housing market may be influenced by the lifestyle they lead, also defined as a series of everyday activities. Lifestyles understood in such a way should be the subject of research concerning the residential environment.

Results of research conducted by scholars show a relationship between lifestyle and the preferred type of property. Demographic and socio-economic variables are no longer sufficient to describe the diversity of target groups and their preferences. Lifestyle understood as a series of actions and activities undertaken by an individual has a strong impact on housing preferences. Knowledge about the lifestyles of potential residents is useful in the process of designing spatial structures and the architectural planning of new residential developments. Housing communities function better when residents share similar lifestyles (HEIJS et al. 2011). Many studies assume that human behaviour is goal-directed and value-oriented. Values are defined as goals that serve as guiding principles in the 
life of a person or a social group. Individuals organize and structure their values to choose among alternative objectives. Such a configuration of values is called a value structure. These structures of values are relatively stable. Some of the values are closely related and have similar meanings, such as pleasure and happiness. Similar values can be organized in groups called value types (MEESTERS 2009).

Residents enter into complex interactions with the housing environment. Functional relationships between a person (resident) and property (dwelling) are called meanings. By examining architectural and urban design characteristics in terms of their meanings we can gain insight into the values and goals of consumers and their expectations as to the housing market.

Residents assign meanings to their residential environment at three hierarchical levels. The top level includes meanings referring to the human system of values and beliefs, while the average level refers to welfare, i.e.: security, abundance, relationships with people and social status. The meanings associated with the highest and middle levels are not openly manifested by the features of the residential environment or the dwelling. The lowest level refers to everyday living activities performed at home. A person reacts emotionally to his or her housing environment. Before one decides to purchase a dwelling, he (or she) analyzes the features of the potential residential environment and answers the question: can this dwelling and its surrounding satisfy all my needs?

Collective interests

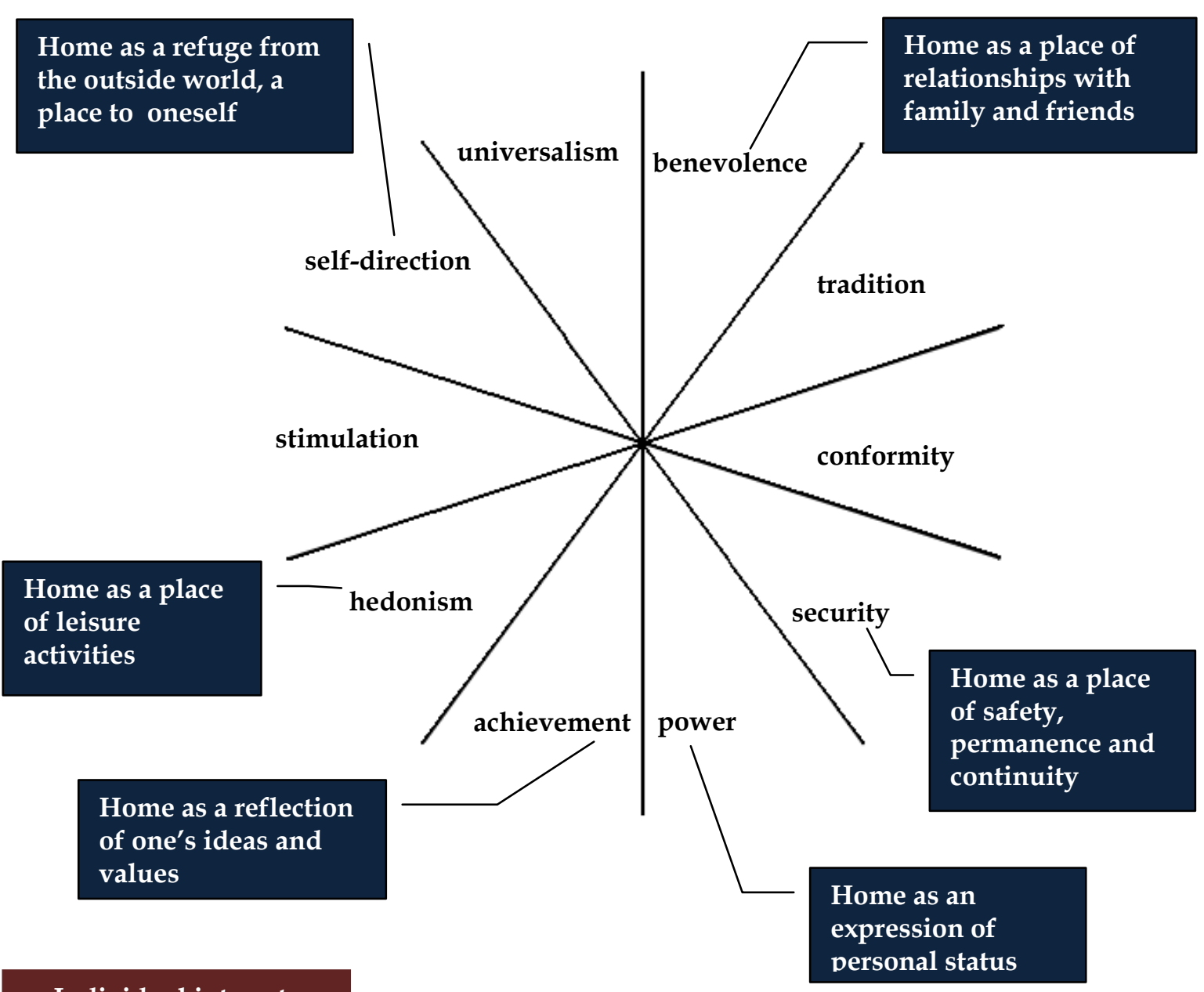

Individual interests

Fig. 1. Meanings assigned to a dwelling in the context of a set of universal values. Source: MEESTERS (2009, p. 13). 
In the context described above, revealing the meanings assigned to living space may have a significant importance to the process of consumer segmentation and examining their preferences. Findings of such research would allow us to better describe and analyze the relationships between core values held by residents and the meanings given to the housing environment through activities performed in the dwelling.

Each activity can have several different meanings, and each of them can be elaborated on in their "submeanings". Figure 2 shows the interdependencies between the housing environment understood as a set of physical properties and the activities performed in the living space, their meanings and submeanings. It also shows how meanings (and submeanings) are assigned to particular activities.

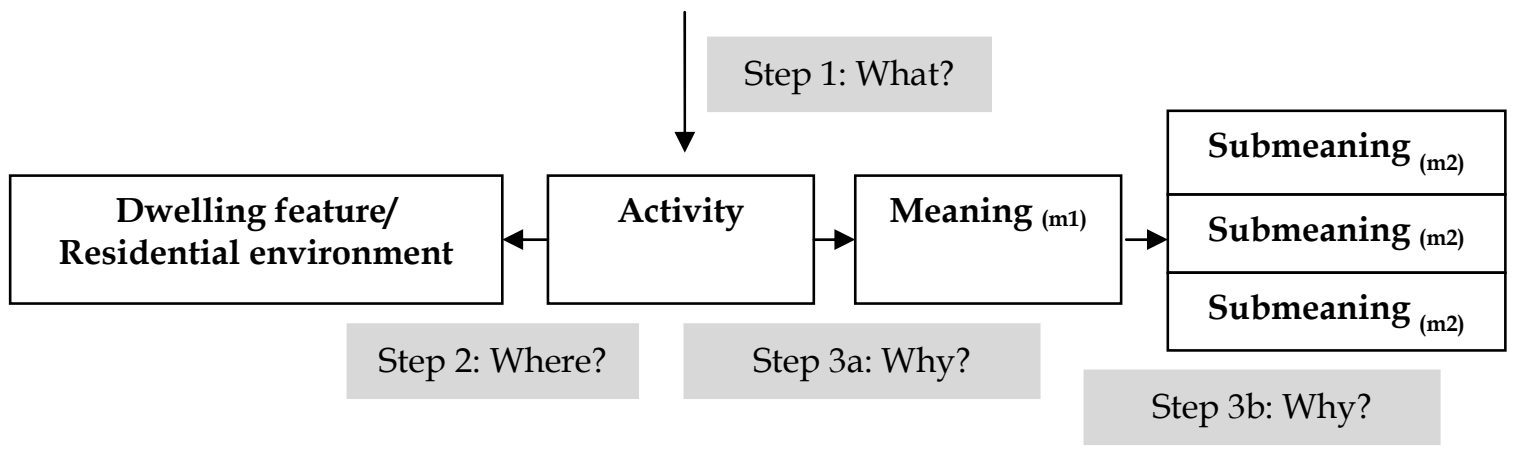

Fig. 2. Activities related to the dwelling and its environment and their meanings. Source: MEESTERS (2009, p. 67).

\subsection{Presentation of the research method}

The results of the test method used in the pilot research allow us to asses: 1) the relationships between rooms in the dwelling and activities assume din them, 2) the meaning of activities assumed at home, 3) the current use and importance of individual rooms to residents. Such data can be collected using a short and simple questionnaire. Information about relations obtained with the questionnaire make it possible to deduce in what rooms (of the dwelling) residents spend the most time, what activities they assume there, and the meanings they assign to these activities. The collected database can then be used to construct a network of relationships not only between the individual rooms and activities assumed within them, but also between the activities and their meanings. The names of rooms are placed in a matrix along with a list of activities. Respondents declare what activities they perform in the particular rooms. The combined values of research results are then recorded in the appropriate cells. The given cell creates a connection between an activity and room. The next step is to create a graphic network of connections (JANSEN et. al. 2011). Activities and rooms are knots (junctions), which are joined together by lines. The differences between various connections can be presented graphically: strong links between knots are presented by thick lines, while weak links are expressed by thin ones.

The pilot study was based on an anonymous survey questionnaire completed by 100 people, of which $81 \%$ were women and $18 \%$ men. It should be noted that $95 \%$ of the respondents were under the age of 25. This fact determined the final research results, because the specific lifestyles of young people influence their dwelling activities as well as meanings assigned to particular activities. They may take on quite different meanings for other segments of consumers. It can therefore be concluded that the residential habits and preferences presented in this paper concern a segment of consumers who are just entering the housing market and searching for first flats which can be adapted to the their individual needs.

\subsection{Relationships between rooms and activities}

Respondents were asked to choose activities taken in the selected types of rooms (e.g. living room, kitchen, bedroom). They then assigned chosen meanings to these activities. Home is a place where people perform a lot of activities, but their number was limited to eleven in the questionnaire (see Table 1).

Figure 3 (based on the results presented in Table 1) shows the strongest network connections between activities and rooms of dwellings. Respondents perform all of the activities suggested in the questionnaire in their living rooms. It can therefore be concluded that it in a contemporary dwelling, 
the living room is a multifunctional room. It is usually the largest room, which integrates family life. It should be noted that three of the 11 proposed activities dominate in the living room: entertaining guests $(86 \%)$, spending time with the nuclear family $(77 \%)$ and watching TV $(76 \%)$. This choice of activities shows that the living room is usually very important for residents, serving as an entertainment center and place of interaction between people. Moreover, the living room provides a place of rest from work: $56 \%$ of the respondents relax and do hobbies here, and $49 \%$ listen to music. In addition to the above, people often eat in the living room (43\%). This can be connected with the type of furniture (big table) in the room, or the habit of eating in front of the TV set. Other actions commonly performed in this room are working and using the computer. Both of these activities were indicated by $36 \%$ of the respondents. It can be presumed that nowadays, when work is mainly done on the computer, the two are very strongly connected.

Table 1

Activities in the selected rooms of a dwelling

\begin{tabular}{|c|c|c|c|c|}
\hline ROOM - TYPE OF USE & 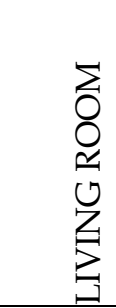 & 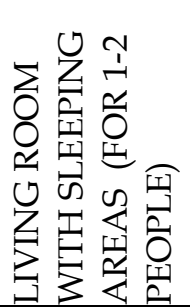 & 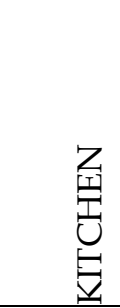 & 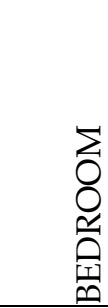 \\
\hline Relaxing/hobbies & $56 \%$ & $37 \%$ & $13 \%$ & $51 \%$ \\
\hline Entertaining guests & $86 \%$ & $24 \%$ & $16 \%$ & $6 \%$ \\
\hline Spending time with the nuclear family & $77 \%$ & $18 \%$ & $37 \%$ & $3 \%$ \\
\hline Working at home & $36 \%$ & $32 \%$ & $19 \%$ & $35 \%$ \\
\hline Using the computer & $36 \%$ & $39 \%$ & $10 \%$ & $53 \%$ \\
\hline Sleeping - taking a nap & $25 \%$ & $40 \%$ & $0 \%$ & $62 \%$ \\
\hline Sleeping at night & $2 \%$ & $27 \%$ & $0 \%$ & $81 \%$ \\
\hline Eating & $43 \%$ & $17 \%$ & $84 \%$ & $7 \%$ \\
\hline Cooking & $1 \%$ & $0 \%$ & $100 \%$ & $0 \%$ \\
\hline Watching TV & $76 \%$ & $22 \%$ & $5 \%$ & $14 \%$ \\
\hline Listening to music & $49 \%$ & $41 \%$ & $32 \%$ & $53 \%$ \\
\hline
\end{tabular}

Source: Own study.

A living room with areas designated for sleeping may serve both as a living room and as a bedroom. It has a very wide range of uses; respondents assigned 10 of the 11 suggested activities to this room (the only activity that is not declared to be performed within it was cooking). It should be noted that no particular activity dominates in this room. On the whole, the room is connected with relaxing activities: listening to music (41\%) and relaxing/hobbies $(37 \%)$, as well as napping $(40 \%)$. Respondents also reported using a computer in this type of room (39\%), (See Table 1).

In the case of the kitchen, 9 different activities are performed. Cooking (100\%) and eating (84\%) clearly dominate. The main use of this room is for preparing meals, however, if it is big enough to include table, the kitchen also serves as a dining room. In addition to this, people spend time together with their nuclear family (37\%) and listen to music (32\%) in the kitchen. This suggests that the radio or another type of music player is on while cooking.

The bedroom is yet another example of a multifunctional room. Of the proposed 11 activities, 10 were reported to take place in the bedroom. As may be expected, sleeping (81\%) and napping (62\%) were the main activities that took place in the bedroom, which is the most comfortable room for resting, at night as well as during the day. Respondents also claimed to listen to music (33\%), relax or do hobbies $(51 \%)$ in the bedroom. Most of the people questioned (53\%) said that they used a computer in the bedroom. Because they also declared resting in the bedroom, it can be assumed that computers are used for entertainment in this room (e.g. watching movies, playing computer games). Finally, it should be added that the bedroom offers a sense of privacy. 
The questionnaire included activities which were most common in Polish homes. What is more, the respondents were asked only about some of the premises in their homes. The living room, living room with a sleeping area and the kitchen are the most commonly used rooms in a dwelling, whereas the bedroom is a rather private zone. Nonetheless, we can observe similar processes occurring in both parts of the home: rooms are becoming multifunctional. Figure 3 shows a circle of three activities that are performed in three or four different rooms. These are: relaxing/hobbies, listening to music and using the computer. Eating, spending time with family and sleeping take place in two rooms. By monitoring the process of changes in the way particular rooms of a dwelling are used, we can propose better design solutions for future homes.

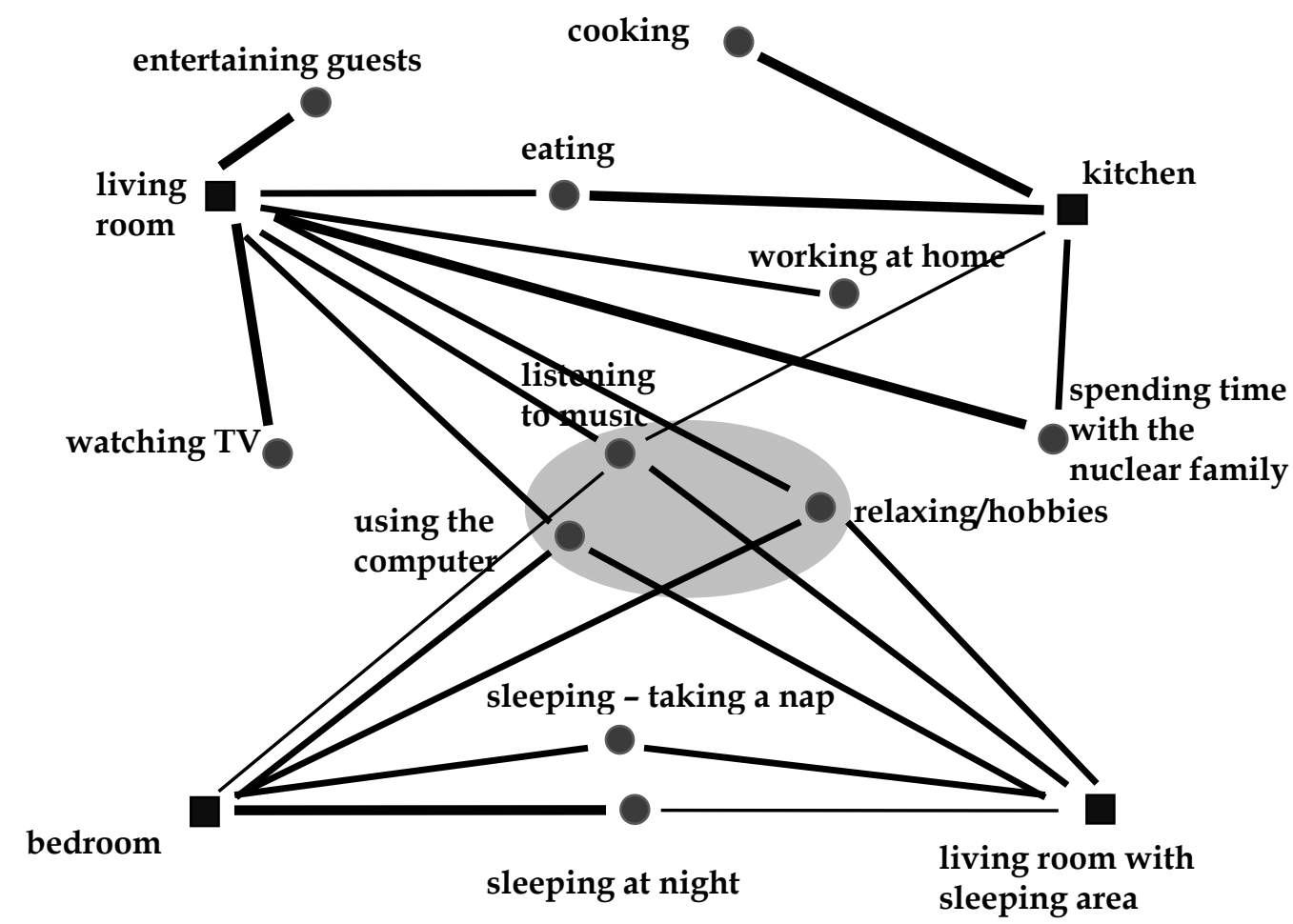

Legend:

Activity - room connections:
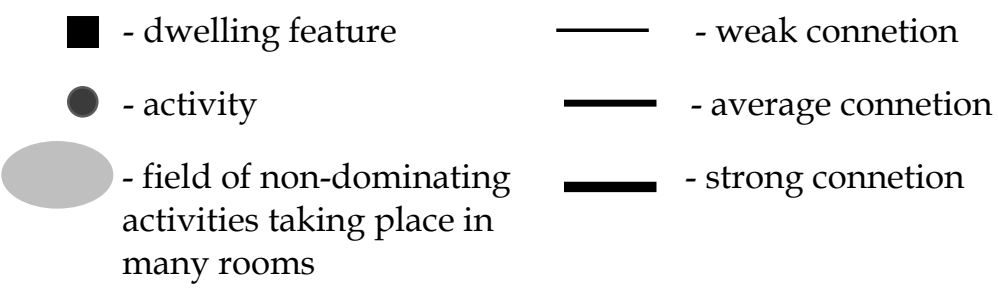

Fig. 3. Network of connections between the rooms of a dwelling and activities performed within them. Source: Own study.

\subsection{Meanings assigned to activities by dwellers (respondents)}

To better understand these changes in the functional structure of dwellings, it is helpful to analyze the meanings assigned to activities. Each activity can have different meanings to a dweller. We can assume that meanings define human activities and their importance to individuals (segments). Table 2 presents the results of research on the meanings of activities assumed in dwellings.

The analysis of the meanings of individual activities should be combined with the study on the activities performed in the different rooms of a dwelling to allow insight into the respondents' 
understanding of living space use, explaining their systems of values and thus, indirectly also informing us of their residential preferences.

Activities preformed in the living room can have a few different meanings. Entertaining guests signifies social contact and hospitality to over $79 \%$ of respondents (see Table 2 ). Well over half of the survey participants enjoy having the opportunity to invite over family members of friends. It can therefore be presumed that the respondents agree with the Polish proverb "When there is a guest in the house, God himself is there". Spending time together with the nuclear family at home means family life $(69 \%)$ to the respondents and a time for one another $(42 \%)$. Watching TV means resting and a time to oneself, but has been also been recognized as a break from work. Listening to music implies a pleasure that $86 \%$ of the respondents claim to enjoy. Working at home, also performed in the living room, is first of all associated with personal development (42\%) and next, multi-tasking (36\%).

Table 2

Selected activities performed in a dwelling and their meanings

\begin{tabular}{|c|c|c|c|c|c|c|c|c|c|}
\hline ACTIVITIES & 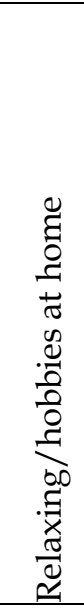 & 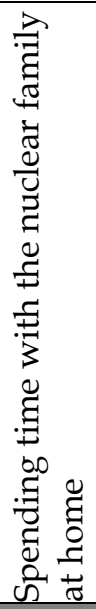 & 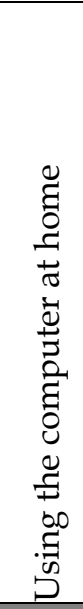 & 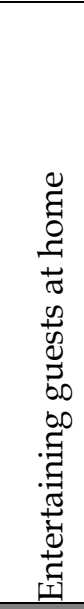 & 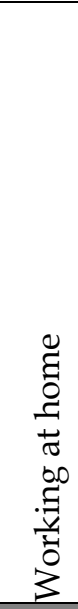 & 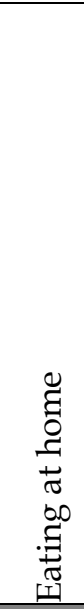 & 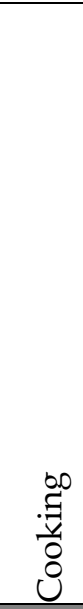 & 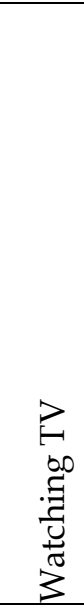 & 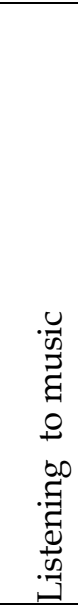 \\
\hline Time to oneself (SD) & $68 \%$ & & & & & & & $41 \%$ & $51 \%$ \\
\hline Personal development (SD) & $35 \%$ & & $18 \%$ & & $42 \%$ & & & $5 \%$ & $9 \%$ \\
\hline Relaxation (HE) & $56 \%$ & & $27 \%$ & & & & & $69 \%$ & $49 \%$ \\
\hline Break from work (ST) & $31 \%$ & & & & & & & $51 \%$ & $20 \%$ \\
\hline Pleasure (HE) & $14 \%$ & & & $6 \%$ & & $11 \%$ & $52 \%$ & & \\
\hline Family life (BE) & & $69 \%$ & & & $17 \%$ & & & & \\
\hline Time for one another (BE) & & $42 \%$ & & & & $30 \%$ & & & \\
\hline Social contacts $(\mathrm{BE})$ & & $17 \%$ & $74 \%$ & $77 \%$ & & $10 \%$ & & & \\
\hline Enjoyment (HE) & & $18 \%$ & & $5 \%$ & & & & $39 \%$ & $86 \%$ \\
\hline Access to information (SD) & & & $77 \%$ & & & & & & \\
\hline Working at home (ST) & & & $47 \%$ & & & & & & \\
\hline Hospitality (BE) & & & & $72 \%$ & & $13 \%$ & $11 \%$ & & \\
\hline Joy (HE) & & & & $57 \%$ & & & & $7 \%$ & $39 \%$ \\
\hline Multi-tasking (ST) & & & & & $36 \%$ & & & & \\
\hline $\begin{array}{l}\text { Spending time with the nuclear } \\
\text { family (BE) }\end{array}$ & & & & & & $62 \%$ & & $25 \%$ & $1 \%$ \\
\hline Health (SE) & & & & & & $53 \%$ & $55 \%$ & & \\
\hline $\begin{array}{l}\text { Eating together with family or } \\
\text { friends (BE) }\end{array}$ & & & & & & & $47 \%$ & & \\
\hline
\end{tabular}

Legend:

SD- self-direction

HE- hedonism

ST- stimulation

BE- benevolence

Source: Own Study. 
People spend a lot of time on the computer in the living room. This activity has two dominant meanings: access to information (77\%) and social ties (74\%). To almost half of the respondents being on the computer also means working from home $(47 \%)$. It is important to note that nowadays a computer can be used for many purposes. Respondents declared that they use the computer to work (in the living room) and relax (in the bedroom). In living rooms with a sleeping area, the same activities are performed as in the living room and thus have the same meanings. An analysis of activities performed in the living room and their meanings has shown this room to be important to the respondents as a place of social contacts and relaxation.

Having meals at home means spending time with family for most people and is also associated with a healthy diet. The respondents appreciate home-made food, which is healthier than that offered in bars and restaurants, so cooking signifies health and a healthy diet to $55 \%$ of the respondents Preparing own food at home makes it possible to control the quality of the ingredients used, which translates into better health. It should also be noted that $52 \%$ of respondents find pleasure in cooking and do not treat it as a necessity or obligation. Cooking at home is closely related to eating, which means spending time together with the nuclear family (37\%).

Activities performed in the bedroom have the same meanings as activities that take place in other rooms. The main activity taking place in this room is sleeping, which has one purpose: to regenerate. Other activities performed in the bedroom are also connected with relaxation, pleasure and time to oneself.

\section{Summary}

Each room in the dwelling has its own uses. However, there are rooms where people perform more activities than in others. Performing an activity in a given room may depend on its equipment and design, as well as on the number of rooms in a dwelling. The findings allowed the authors to identify the relationship between the activities performed in a dwelling (in particular rooms) and their meanings. Assigning activities to the selected types of rooms in a dwelling facilitates a better understanding of the functional scheme of living space and makes it possible to precisely describe the use of a selected room. The study shows how new lifestyles determine the use of the living environment and finally, how to modify user preferences.

The research results also show the diversity and wide range of meanings that respondents assign to activities. One activity can have many meanings, and some meanings pertain to a few activities at the same time. People decide to perform an activity when its meanings are congruent with their system of values.

The analysis of the research results showed that the living room has many uses: people spend time with their families and entertain guests there. Moreover, it is a place of work as well as relaxation. The living room is undoubtedly the center for family life. The kitchen is a place where dwellers not only cook but also eat, with the later activity also assumed in the living room. Cooking and eating are of significant importance, thus the kitchen also becomes a place where people spend time with family. The bedroom on the other hand is a place of relaxation and regeneration, as well as a room where residents use computers.

The residential market in Poland is highly competitive. Knowledge of consumers' preferences in regards to residential housing is very valuable for developers and architects. Due to the fact that human expectations and aspirations vary over time such data should be regularly updated. The survey method presented above allows residential preferences to be assessed in a new, quick and simple way. The findings reveal differences in how living space is used by residents as well as diverse meanings assigned to activities assumed in the housing environment. Such knowledge of residents' attitudes may support consumer segmentation and result in better housing design.

\section{References}

Buckenberger C., Meanings of housing qualities in suburbia: empirical evidence from Auckland, New Zealand, Journal of Housing and the Built Environment Vol. 27 (2012), s. 72.

Heijs W., van Deurser A., Leussink M., Smeets J., Re-searching the labyrinth of life-styles, Journal of Housing and the Built Environment Vol. 26 (2011), s. 412-413.

Jansen S. J. T., Coolen H.C.C.H, Goetgeluk R.W., The Measurement and Analysis of Housing Preference and Choice. Springer, Dordrecht Heidelberg London New York 2011, s. $92-93$. 
Jansen S. J. T., What is the worth of values in guiding residential preferences and choices?, Journal of Housing and the Built Environment Vol. 27 (2012), s. 274.

Meesters J., The meaning of activities in the dwelling and residential environment. A structural approach in people-environment relations, Sustainable Urban Areas No 27, Delft University of Technology, 2009, s. 1, 13, 67.

Nykiel L., Potencjał rynku mieszkaniowego jako przedmiotu finansowania, Studia i Materiały Towarzystwa Naukowego Nieruchomości vol. 14, nr 1 2006, Olsztyn 2006, s. 188 (Nykiel L., The potential of housing environment as a subject of funding, Journal Of The Polish Estate Scientific Society, vol. 14, nr 1 2006, Olsztyn 2006, p. 188).

Stachura E., Środowisko mieszkaniowe w Polsce. Ocena, oczekiwania, aspiracje, Wydawnictwo Politechniki Krakowskiej, Kraków 2013, s. 209 (Stachura E., Housing market in Poland. Assessment, expectations, aspirations, Cracow University of Technology Publishing, Cracow 2013, p. 209).

Strączkowski Ł., Motywy zakupu mieszkań w świetle badań nabywców na lokalnym rynku mieszkaniowym w Poznaniu, Studia i Materiały Towarzystwa Naukowego Nieruchomości vol. 17, nr 2 2009, Olsztyn 2009, s. 45 (Straczkowski Ł., The motives of purchase on flats in light of the buyers' research on local housing market in Poznań, Journal Of The Polish Estate Scientific Society, vol. 17, nr 2 2009, Olsztyn 2009, p. 45).

Van Diepen A. M. L., Musterd S., Lifestyles and the city: connecting daily life to urbanity, Journal of Housing and the Built Environment Vol. 24 (2009), s. 332. 